\title{
$\mu$-Opioids activate phospholipase C in SH-SY5Y human neuroblastoma cells via calcium-channel opening
}

\author{
Darren SMART, Graham SMITH and David G. LAMBERT* \\ University Department of Anaesthesia, Leicester Royal Infirmary, Leicester LE1 5WW, U.K.
}

We have recently reported that, in SH-SY5Y cells, $\mu$-opioid receptor occupancy activates phospholipase $C$ via a pertussis toxin-sensitive G-protein. In the present study we have further characterized the mechanisms involved in this process. Fentanyl $(0.1 \mu \mathrm{M})$ caused a monophasic increase in inositol 1,4,5-trisphosphate mass formation, with a peak $(20.5 \pm 3.6 \mathrm{pmol} / \mathrm{mg}$ of protein) at $15 \mathrm{~s}$. Incubation in $\mathrm{Ca}^{2+}$-free buffer abolished this response, while $\mathrm{Ca}^{2+}$ replacement 1 min later restored the stimulation of inositol 1,4,5-trisphosphate formation $(20.1 \pm 0.6 \mathrm{pmol} /$ $\mathrm{mg}$ of protein). In addition, nifedipine ( $1 \mathrm{nM}-0.1 \mathrm{mM})$, an Ltype $\mathrm{Ca}^{2+}$-channel antagonist, caused a dose-dependent inhi- bition of inositol 1,4,5-trisphosphate formation, with an $\mathrm{IC}_{50}$ of $60.3 \pm 1.1 \mathrm{nM}$. Elevation of endogenous $\beta / \gamma$ subunits by selective activation of $\delta$-opioid and $\alpha_{2}$ adrenoceptors failed to stimulate phospholipase $\mathrm{C}$. Fentanyl also caused a dose-dependent $\left(\mathrm{EC}_{50}\right.$ of $16.2 \pm 1.0 \mathrm{nM}$ ), additive enhancement of carbachol-induced inositol 1,4,5-trisphosphate formation. In summary, we have demonstrated that in SH-SY5Y cells activation of the $\mu$-opioid receptor allows $\mathrm{Ca}^{2+}$ influx to activate phospholipase $\mathrm{C}$. However, the possible role of this mechanism in the process of analgesia remains to be elucidated.

\section{INTRODUCTION}

Activation of opioid receptors has generally been considered to have inhibitory effects on neuronal post-receptor events (North, 1989; Childers, 1991). However, opioids also have excitatory effects on neuronal activity (Crain and Shen, 1990). For example, it has been shown that opioids can stimulate $3^{\prime}, 5^{\prime}$-cyclic adenosine monophosphate (cAMP) formation via a pertussis toxin-sensitive G-protein in neuronal cells from the rat olfactory bulb (Olianas and Onali, 1993). Furthermore, we have recently reported that, in SH-SY5Y human neuroblastoma cells, $\mu$-opioids cause a transient, monophasic increase in inositol 1,4,5-trisphosphate $\left[\operatorname{Ins}(1,4,5) P_{3}\right]$ formation, which involves a pertussis toxin-sensitive G-protein and is blocked by $\mathrm{Ni}^{2+}$ (Smart et al., 1994a).

One possible mechanism for this stimulation of $\operatorname{Ins}(1,4,5) P_{3}$ formation by opioids is that $\beta / \gamma$ subunits from $G_{i} / G_{0}$ could activate a $\mathrm{Ca}^{2+}$-sensitive isoform of phospholipase $\mathrm{C}$ (PLC) such as PLC $\beta 2$ or PLC $\beta 3$ (Camps et al., 1992; Carozzi et al., 1993). However, only activation of the $\mu$-opioid receptor in SH-SY5Y cells stimulates Ins $(1,4,5) P_{3}$ formation (Smart et al., 1994a), yet both $\mu$ - and $\delta$-opioid receptors couple to $\mathrm{G}_{\mathrm{i}}$. Since there are 2-5fold more $\mu$ than $\delta$ (and no $\kappa$ ) receptors in these cells (Yu et al., 1986), $\delta$-receptor activation may not liberate sufficent $\beta / \gamma$ subunits to activate PLC. SH-SY5Y cells also express $\alpha_{2}$ adrenoceptors, which couple via $G_{i}$ to inhibit adenylate cyclase activity (Lambert and Nahorski, 1990a). Levels of $\alpha_{2}$ expression are similar to those of the $\delta$-opioid receptor.

Alternatively, the $\mu$-opioid receptor could mediate the opening of a $\mathrm{Ca}^{2+}$ channel, allowing $\mathrm{Ca}^{2+}$-influx-dependent activation of a $\mathrm{Ca}^{2+}$-sensitive isoform of PLC. SH-SY5Y cells possess both Land $\mathrm{N}$-type voltage-sensitive $\mathrm{Ca}^{2+}$ channels (VSCC) (Toselli et al., 1991; Morton et al., 1992), and opioids have been shown to open VSCCs in NG108-15 cells and astrocytes (Jin et al., 1992; Eriksson et al., 1993), although it should be emphasized that opioids generally close VSCCs (Porzig, 1990).

In this study we have addressed both of these hypotheses. First, we increased the intracellular concentration of $\beta / \gamma$ subunits from $G_{1}$ by selective activation of $\mu-, \delta$ - and $\alpha_{2}$-receptors. Secondly, we further characterized the $\mathrm{Ca}^{2+}$ dependency of the $\mu$ opioid stimulation of $\operatorname{Ins}(1,4,5) P_{3}$ formation. We have shown that, in SH-SY5Y cells, activation of the $\mu$-opioid receptor allows $\mathrm{Ca}^{2+}$ influx to activate PLC.

\section{MATERIALS AND METHODS}

\section{Cell culture and harvesting}

SH-SY5Y human neuroblastoma cells (passages 70-90) were cultured in Minimum Essential Medium with Earle's salts supplemented with $2 \mathrm{mM}$ L-glutamine, $100 \mathrm{i} . \mathrm{u} . / \mathrm{ml}$ penicillin, $100 \mu \mathrm{g} / \mathrm{ml}$ streptomycin, $2.5 \mu \mathrm{g} / \mathrm{ml}$ fungizone, and $10 \%$ fetal calf serum (GIBCO, U.K.).

Cells were harvested with $10 \mathrm{mM}$ Hepes-buffered saline/ $0.02 \%$ EDTA, pH 7.4, washed twice with, and then resuspended

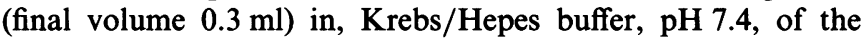
following composition (in $\mathrm{mM}$ ), unless stated otherwise below: $\mathrm{Na}^{+}, 143.3 ; \mathrm{K}^{+}, 4.7 ; \mathrm{Ca}^{2+}, 2.5 ; \mathrm{Mg}^{2+}, 1.2 ; \mathrm{Cl}^{-}, 125.6 ; \mathrm{HCO}_{3}^{-}, 25$; $\mathrm{H}_{2} \mathrm{PO}_{4}^{-}, 1.2 ; \mathrm{SO}_{4}{ }^{2-}, 1.2$; glucose, 11.7; and Hepes, 10.

\section{Measurement of Ins $(1,4,5) P_{3}$}

Whole-cell suspensions $(0.3 \mathrm{ml})$ were preincubated at $37^{\circ} \mathrm{C}$ in $\mathrm{Ca}^{2+}$-containing or $\mathrm{Ca}^{2+}$-free buffer, with or without naloxone $(1 \mu \mathrm{M})$, atropine $(1 \mu \mathrm{M})$ or nifedipine $(1 \mathrm{nM}-0.1 \mathrm{mM})$ for

Abbreviations used: $\left[\mathrm{Ca}^{2+}\right]_{i}$, intracellular concentration of free calcium; cAMP, $3^{\prime}, 5^{\prime}$-cyclic adenosine monophosphate; PLC, phospholipase $\mathrm{C}$; Ins $(1,4,5) P_{3}$, inositol 1,4,5-trisphosphate; DAMGO, [D-Ala ${ }^{2}$, MePhe ${ }^{4}$, Gly(ol) ${ }^{5}$ ]enkephalin; DPDPE, [D-Pen ${ }^{2,5}$ ]enkephalin; IBMX, isobutylmethylxanthine; VSCC, voltage-sensitive calcium channels; ROCC, receptor-operated calcium channels.

* To whom all correspondence should be addressed. 
$15 \mathrm{~min}$. The cell suspensions were then incubated with fentanyl (1 nM-10 $\mu \mathrm{M})$, carbachol $(0.1 \mu \mathrm{M}-1 \mathrm{mM})$, [D-Ala ${ }^{2}, \mathrm{MePhe}^{4}$, Gly $(\mathrm{ol})^{5}$ ]enkephalin (DAMGO; $1 \mu \mathrm{M}$ ), [D-Pen ${ }^{2,5}$ ]enkephalin (DPDPE; $10 \mu \mathrm{M})$, or clonidine $(1 \mu \mathrm{M})$ in various combinations for 0-300 s. In some studies, cells were suspended in $\mathrm{Ca}^{2+}$-free buffer 1-2 min before incubation with fentanyl $(0.1 \mu \mathrm{M})$ and the $\mathrm{Ca}^{2+}(2.5 \mathrm{mM})$ subsequently replaced (1-11 min later). Reactions were terminated by the addition of $0.3 \mathrm{ml}$ of $1 \mathrm{M}$ trichloroacetic acid.

Ins $(1,4,5) P_{3}$ was extracted with Freon/octylamine $(1: 1, \mathrm{v} / \mathrm{v})$ and neutralized with $25 \mathrm{mM} \mathrm{NaHCO}_{3}$. Ins $(1,4,5) P_{3}$ was assayed using a bovine adrenocortical binding protein and $\left[{ }^{3} \mathrm{H}\right]-$ Ins $(1,4,5) P_{3}(41 \mathrm{Ci} / \mathrm{mol}$; Amersham, U.K. $)$ at $4{ }^{\circ} \mathrm{C}$. Authentic Ins $(1,4,5) P_{3}(0.036-12 \mathrm{pmol}$; Siemat, U.K.) in buffer, taken through an identical extraction process, was used as a standard. Non-specific binding was defined in the presence of excess Ins $(1,4,5) P_{3}(0.3 \mathrm{nmol})$. Bound $\left[{ }^{3} \mathrm{H}\right] \operatorname{Ins}(1,4,5) P_{3}$ was separated by rapid vacuum filtration (Challiss et al., 1988).

\section{Measurement of CAMP}

Whole-cell suspensions $(0.3 \mathrm{ml})$ were incubated in the presence of isobutylmethylxanthine (IBMX) $(1 \mathrm{mM})$, with or without fentanyl $(1 \mu \mathrm{M})$ at $37^{\circ} \mathrm{C}$ for $0-300 \mathrm{~s}$. Reactions were terminated by the addition of $20 \mu \mathrm{l}$ of $\mathrm{HCl}(10 \mathrm{M}), 20 \mu \mathrm{l}$ of $\mathrm{NaOH}(10 \mathrm{M})$, and $180 \mu \mathrm{l}$ of Tris (1 M, pH 7.5). The concentration of cAMP was measured in the supernatants by a specific radiolabelled receptor assay, as described previously (Brown et al., 1971).

\section{Data analysis}

All data are given as mean \pm S.E.M. unless otherwise stated, and are shown as primary data ( $\mathrm{pmol} / \mathrm{mg}$ of protein) throughout, although some variation between passages does occur. $\mathbf{E C}_{50}$ (half-maximal stimulation) and $\mathrm{IC}_{50}$ (half-maximal inhibition) values were obtained by computer-assisted curve fitting using GRAPHPAD. Statistical comparisons made where appropriate by Student's $t$-test (paired or unpaired) and/or ANOVA and were considered significant when $P<0.05$.

\section{RESULTS}

Fentanyl $(0.1 \mu \mathrm{M})$ caused a monophasic increase in $\operatorname{Ins}(1,4,5) P_{3}$ formation, which peaked $(26.5 \pm 3.6 \mathrm{pmol} / \mathrm{mg}$ of protein) at $15 \mathrm{~s}$ and returned to basal levels $(6.0 \pm 0.5 \mathrm{pmol} / \mathrm{mg}$ of protein) between 1 and 2 min (Figure 1), as previously reported (Smart et al., 1994a). In contrast, fentanyl $(1 \mu \mathrm{M})$ inhibited cAMP formation, with maximum inhibition $(40 \%)$ occurring in $30 \mathrm{~s}$ and being maintained as long as the agonist remained on the receptor (Figure 1), although it should be noted that phosphodiesterase activity was inhibited with IBMX.

DAMGO $(1 \mu \mathrm{M})$ stimulated $\operatorname{Ins}(1,4,5) P_{3}$ formation at $15 \mathrm{~s}$, while DPDPE $(10 \mu \mathrm{M})$ and clonidine $(1 \mu \mathrm{M})$, alone or in combination, did not (Table 1). Indeed, neither DPDPE nor clonidine had any effect on $\operatorname{Ins}(1,4,5) P_{3}$ formation throughout the entire 0-300 s time course (results not shown). Furthermore, neither DPDPE $(10 \mu \mathrm{M})$ nor clonidine $(1 \mu \mathrm{M})$, alone or in combination, enhanced the stimulation of $\operatorname{Ins}(1,4,5) P_{3}$ formation caused by a submaximal dose of DAMGO $(1 \mu \mathrm{M})$ (Table 1$)$.

Fentanyl $(0.1 \mu \mathrm{M})$ had no effect on $\operatorname{Ins}(1,4,5) P_{3}$ formation in $\mathrm{Ca}^{2+}$-free buffer, as previously reported (Smart et al., 1994a). However, when $\mathrm{Ca}^{2+}(2.5 \mathrm{mM})$ was replaced 1 min after the fentanyl challenge, there was a subsequent substantial stimulation of $\operatorname{Ins}(1,4,5) P_{3}$ formation (Figure 2). This response was timedependent as, while $\mathrm{Ca}^{2+}$ replacement at 2 min caused a small but

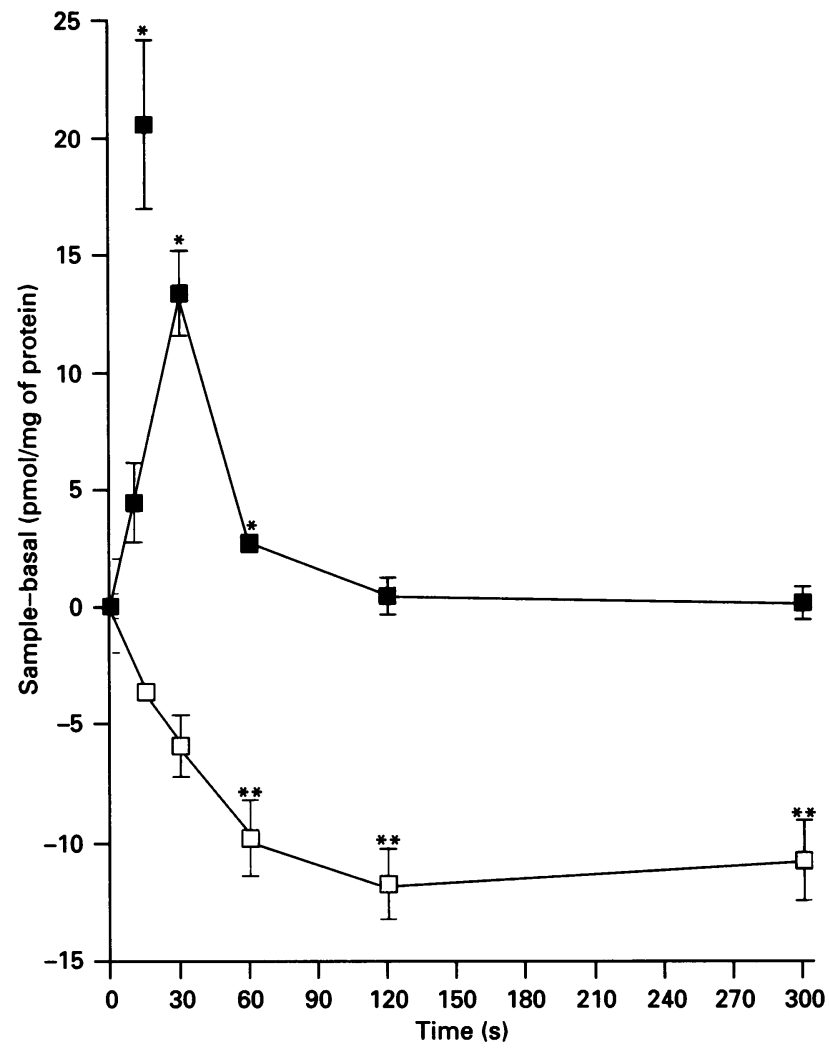

Figure 1 The effects of fentanyl on Ins(1,4,5) $P_{3}$ and CAMP formation in SHSY5Y cells

Cell suspensions $(0.3 \mathrm{ml})$ were incubated with fentanyl $(0.1 \mu \mathrm{M})$ for $0-300 \mathrm{~s}$. Ins $(1,4,5) P_{3}$ and cAMP were measured by specific radio-receptor mass assays. Data are mean \pm S.E.M., where $n=3$. Whole curves for Ins $(1,4,5) P_{3}$ formation $(\square)$ and cAMP formation $(\square)$ are $P<0.05$ by ANOVA. * denotes $P<0.05$ (ttest) increased compared with basal, and ${ }^{*}$ denotes $P<$ 0.05 (t-test) decreased compared with basal.

\section{Table 1 Ins $(1,4,5) P_{3}$ formation following $G_{1}$ activation in SH-SY5Y cells}

Whole-cell suspensions $(0.3 \mathrm{ml})$ were preincubated at $37^{\circ} \mathrm{C}$ for $15 \mathrm{~min}$, and then incubated with various combinations of DAMGO $(1 \mu \mathrm{M}), \operatorname{DPDPE}(10 \mu \mathrm{M})$ and clonidine $(1 \mu \mathrm{M})$ for $15 \mathrm{~s}$. Ins $(1,4,5) P_{3}$ was measured by a specific radio-receptor mass assay. All results are mean \pm S.E.M. * denotes significantly $(P<0.05$, $t$-test $)$ increased compared with basal.

\begin{tabular}{lcc}
\hline & & $\begin{array}{c}\text { Ins }(1,4,5) P_{3} \\
\text { (pmol/mg } \\
\text { of protein) }\end{array}$ \\
\hline Addition & $n$ & $5.2 \pm 0.4$ \\
None & 5 & $9.3 \pm 0.6$ \\
DPDPE & 5 & $7.3 \pm 0.6$ \\
Clonidine & 5 & $8.9 \pm 0.7$ \\
DPDPE + clonidine & 5 & $27.7 \pm 1.0^{*}$ \\
DAMGO & 5 & $27.3 \pm 1.1^{*}$ \\
DAMGO + DPDPE & 5 & $27.4 \pm 0.7^{\star}$ \\
DAMGO + clonidine & 5 & $27.5 \pm 1.0^{*}$ \\
DAMGO + DPDPE + clonidine & &
\end{tabular}

significant $(P<0.05)$ stimulation of $\operatorname{Ins}(1,4,5) P_{3}$ formation, $\mathrm{Ca}^{2+}$ replacement at $4 \mathrm{~min}$ or later was ineffective (Figure 2 inset). In addition, nifedipine $(1 \mathrm{nM}-0.1 \mathrm{mM})$, an L-type $\mathrm{Ca}^{2+}$-channel antagonist (Spedding and Paoletti, 1992), caused a dose-de- 


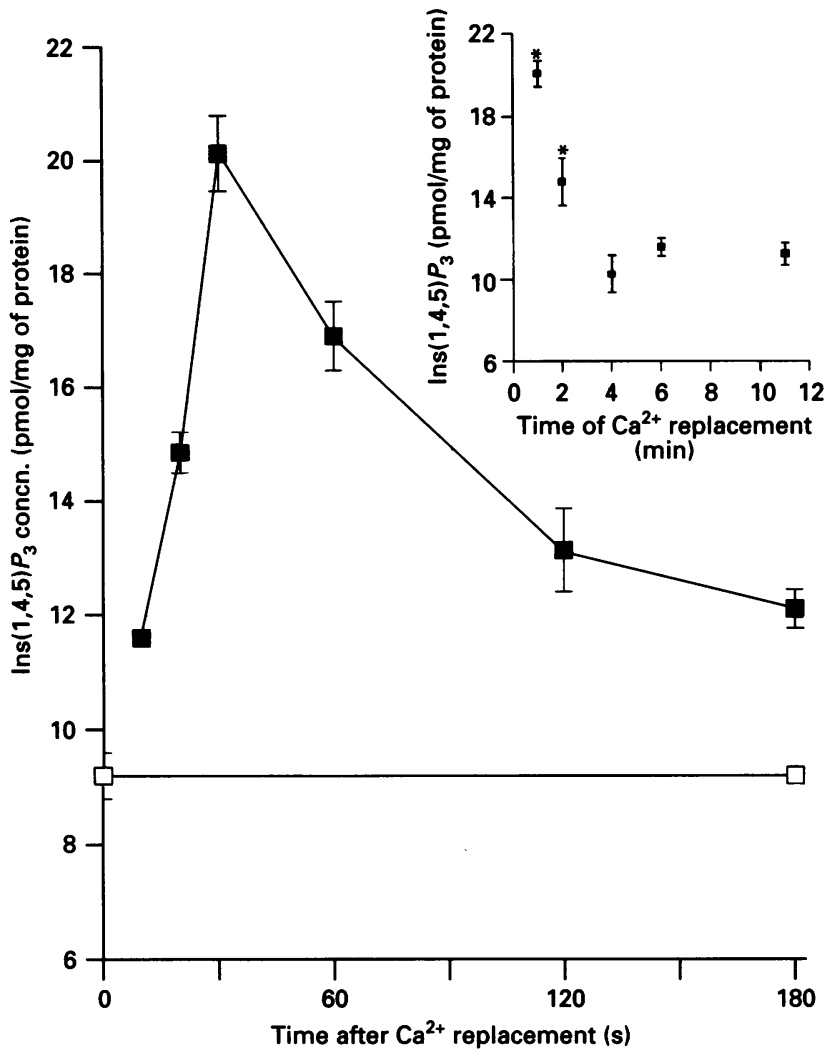

Figure 2 Effect of $\mathrm{Ca}^{2+}$ replacement on fentanyl-induced Ins $(1,4,5) P_{3}$ formation

Main panel depicts time course of fentanyl-induced Ins $(1,4,5) P_{3}$ formation following $\mathrm{Ca}^{2+}$ replacement at $1 \mathrm{~min}$. Inset shows that the effect of $\mathrm{Ca}^{2+}$ replacement was time dependent. Whole-cell suspensions were preincubated in $\mathrm{Ca}^{2+}$-free buffer at $37^{\circ} \mathrm{C}$ for $15 \mathrm{~min}$, and then incubated with fentanyl $(0.1 \mu \mathrm{M})$ for $0-11 \mathrm{~min}$ before the $\mathrm{Ca}^{2+}(2.5 \mathrm{mM})$ was $(\square)$, or was not $(\square)$, replaced. Data are mean \pm S.E.M., where $n=5$. Whole time course $P<0.05$ by ANOVA. * denotes $P<0.05$ ( $($ test) increased compared with basal.

pendent inhibition of fentanyl-stimulated Ins $(1,4,5) P_{3}$ formation, with an $\mathrm{IC}_{50}$ of $60.3 \pm 1.1 \mathrm{nM}$ (Figure 3).

Carbachol $(100 \mu \mathrm{M})$ caused a biphasic stimulation of Ins $(1,4,5) P_{3}$ formation (Figure 4), which rose from basal $(12.8 \pm 1.2 \mathrm{pmol} / \mathrm{mg}$ of protein) to a peak (8.2-fold basal) at $10 \mathrm{~s}$ and then declined until $60 \mathrm{~s}$ to a steady plateau phase $(1.8$-fold basal) which was maintained until sampling ended (300 s). Basal Ins $(1,4,5) P_{3}$ did not change over the $300 \mathrm{~s}$ time course (Figure 4 and data not shown). The peak phase, which releases $\mathrm{Ca}^{2+}$ from the intracellular stores, is $\mathrm{Ca}^{2+}$ independent, while the plateau phase, which may or may not release $\mathrm{Ca}^{2+}$, is dependent on the influx of extracellular $\mathrm{Ca}^{2+}$ (Lambert and Nahorski, 1990b), via non-voltage-sensitive $\mathrm{Ca}^{2+}$ channels (Lambert et al., 1990).

Fentanyl $(0.1 \mu \mathrm{M})$ enhanced carbachol-induced Ins $(1,4,5) P_{3}$ formation at both the peak (by $20.8 \mathrm{pmol} / \mathrm{mg}$ of protein) and plateau (by $16.0 \mathrm{pmol} / \mathrm{mg}$ of protein) phases (Figure 4). However, neither DPDPE $(10 \mu \mathrm{M})$ nor clonidine $(1 \mu \mathrm{M})$ enhanced carbachol-stimulated Ins $(1,4,5) P_{3}$ formation (results not shown). The enhancement of carbachol-stimulated Ins $(1,4,5) P_{3}$ formation by fentanyl was simply additive, rather than synergistic, with the carbachol component being totally reversed by atropine, as was the opioid component by naloxone (Table 2). Furthermore, this opioid-muscarinic interaction was dose-dependent for both fentanyl and carbachol (results not shown), with the $\mathrm{EC}_{50}$ values

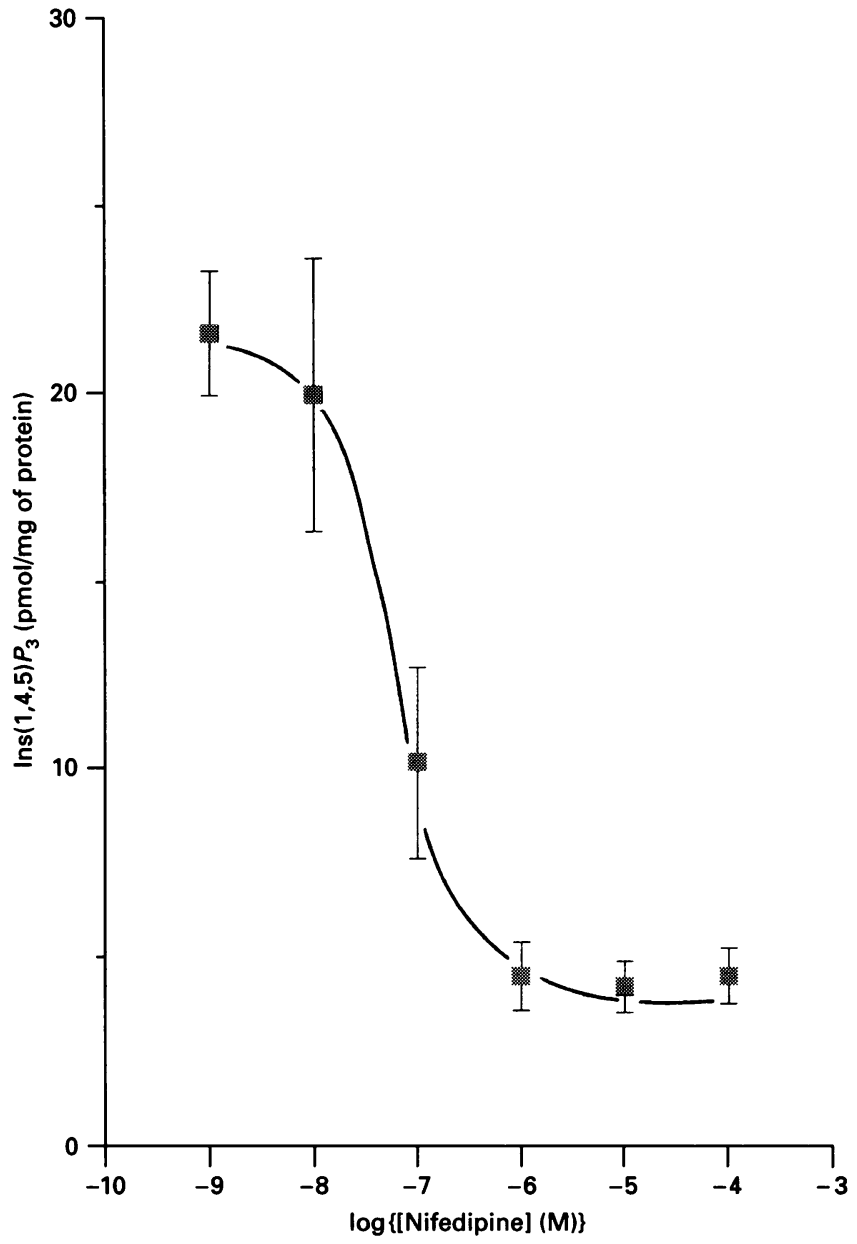

Figure 3 Dose-dependent inhibition of fentanyl-induced Ins $(1,4,5) P_{3}$ formation by nifedipine

Whole-cell suspensions were preincubated at $37^{\circ} \mathrm{C}$ with nifedipine $(1 \mathrm{nM}-0.1 \mathrm{mM})$ for $15 \mathrm{~min}$, and then incubated with fentanyl $(0.1 \mu \mathrm{M})$ for 15 s. Data are mean \pm S.E.M., where $n=5$. Basal Ins $(1,4,5) P_{3}$ formation was $4.1 \pm 0.4 \mathrm{pmol} / \mathrm{mg}$ of protein.

for the enhancement of carbachol-induced Ins $(1,4,5) P_{3}$ formation by fentanyl $(16.2 \pm 1.0 \mathrm{nM})$ and the enhancement of fentanylinduced $\operatorname{Ins}(1,4,5) P_{3}$ formation by carbachol $(12.0 \pm 1.9 \mu \mathrm{M})$ being similar to their previously reported $\mathrm{EC}_{50}$ values for the stimulation of basal $\operatorname{Ins}(1,4,5) P_{3}$ formation (Smart et al., 1994a,b).

\section{DISCUSSION}

We report here, for the first time in a neuronal preparation, that activation of the $\mu$-opioid receptor allows $\mathrm{Ca}^{2+}$ influx to stimulate PLC activity, resulting in increased Ins $(1,4,5) P_{3}$ formation. Rises in $\operatorname{Ins}(1,4,5) P_{3}$ concentrations have been implicated in a number of cellular responses, most notably the release of $\mathrm{Ca}^{2+}$ from intracellular stores and possibly $\mathrm{Ca}^{2+}$ entry (Berridge, 1993). Moreover, it has been proposed that $\operatorname{Ins}(1,4,5) P_{3}$-induced rises in intracellular $\mathrm{Ca}^{2+}$ concentrations $\left(\left[\mathrm{Ca}^{2+}\right]_{\mathrm{i}}\right)$ increase $\mathrm{K}^{+}$efflux, and thus cause hyperpolarization, and that this may be one of the mechanisms underlying morphine analgesia (Lipp, 1991).

In the current study, fentanyl stimulated $\operatorname{Ins}(1,4,5) P_{3}$ formation and inhibited cAMP formation. While opioids are generally 


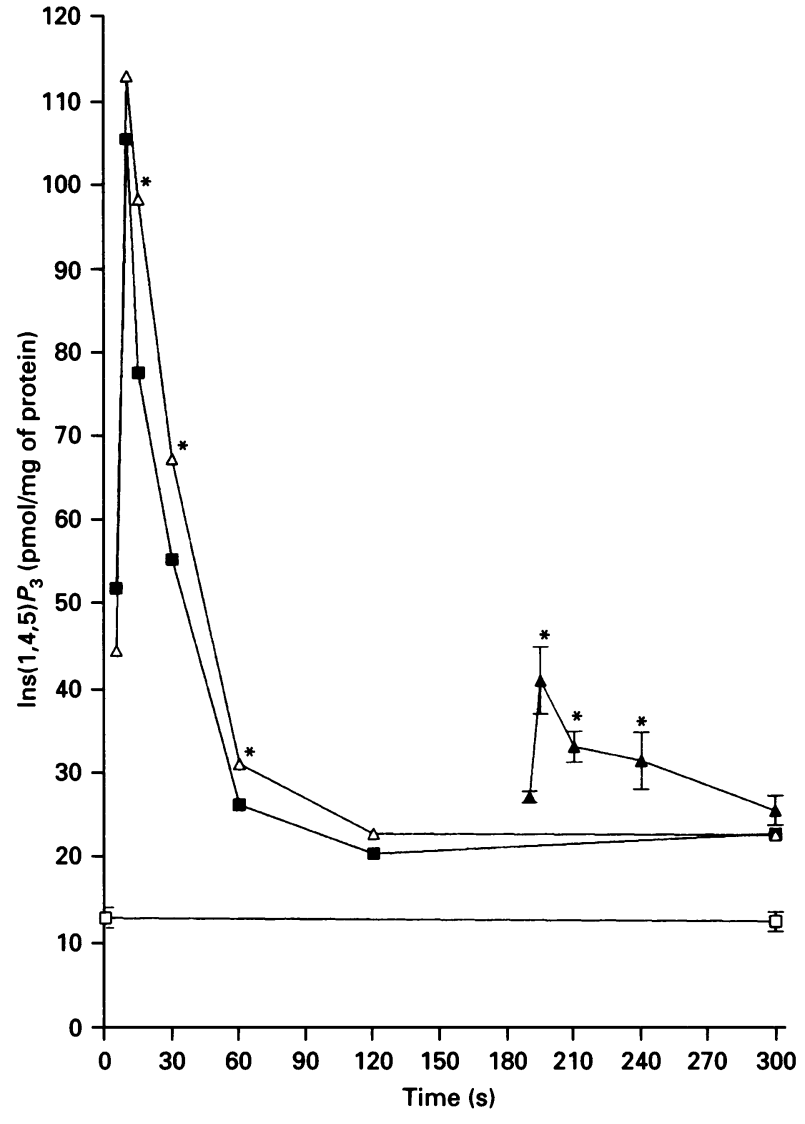

Figure 4 Fentanyl enhances carbachol-induced Ins $(1,4,5) P_{3}$ formation in SH-SY5Y cells

Cells were incubated with $(\square)$ or without $(\square)$ carbachol $(\mathrm{CCh})(0.1 \mathrm{mM})$ for $0-300 \mathrm{~s}$. Fentanyl $(0.1 \mu \mathrm{M})$ was added to some of the cell suspensions either $0 \mathrm{~s}(\triangle)$ or $180 \mathrm{~s}(\mathbf{\Delta})$ after $\mathrm{CCh}$. Data are mean \pm S.E.M., where $n=5$. Error bars have been omitted from the $\mathrm{CCh}$ and $\mathrm{CCh}+$ Fentanyl $(0 \mathrm{~s})$ time courses for clarity (both $P<0.05$ by ANOVA). ${ }^{*}$ denotes $P<0.05$ (paired $\mathrm{H}$-est) increased compared with CCh.

Table 2 The enhancement of carbachol-induced Ins $(1,4,5) P_{3}$ by fentanyl is additive

Whole-cell suspensions $(0.3 \mathrm{ml})$ were preincubated, with or without naloxone $(1 \mu \mathrm{M})$ or atropine $(1 \mu \mathrm{M})$, at $37^{\circ} \mathrm{C}$ for $15 \mathrm{~min}$. The cells were then incubated in the presence or absence of fentanyl $(0.1 \mu \mathrm{M})$ and/or carbachol $(C C h, 0.1 \mathrm{mM})$ for $15 \mathrm{~s}$. All results are mean \pm S.E.M. $(n=4-5)$. ${ }^{*}$ denotes significantly $(P<0.05$, $t$-test) increased compared with CCh alone. $\dagger$ denotes significantly $(P<0.05$, $k$ test $)$ decreased compared with $\mathrm{CCh}$ alone.

\begin{tabular}{lr}
\hline Addition(s) & $\begin{array}{l}\text { Ins }(1,4,5) P_{3} \\
\text { (pmol/mg } \\
\text { of protein) }\end{array}$ \\
\hline None & $6.5 \pm 0.3$ \\
CCh & $42.9 \pm 4.8$ \\
Fentanyl & $16.0 \pm 1.0$ \\
CCh + fentanyl & $55.9 \pm 4.8^{*}$ \\
CCh + fentanyl + atropine & $16.3 \pm 1.3 \dagger$ \\
CCh + fentanyl + naloxone & $40.7 \pm 6.7$
\end{tabular}

considered to have inhibitory effects on neuronal activity, e.g. causing hyperpolarization and reducing neurotransmitter release (North, 1989), excitatory actions, such as depolarization and increased neurotransmitter release, have also been reported (Crain and Shen, 1990). Opioids usually inhibit cAMP formation (as confirmed here) and have little or no effect on $\operatorname{Ins}(1,4,5) P_{3}$ formation (Childers, 1991), but opioid-induced stimulation of the production of both second messengers in neuronal tissues has recently been reported (Olianas and Onali, 1993; Smart et al., 1994a). Noteably, in this study fentanyl, over the same dose range, stimulated one second messenger while inhibiting the other. Although dual excitatory and inhibitory effects of opioids in neuronal tissue have been reported previously (Higashi et al., 1982; Jin et al., 1992), the type of effect seen depended on the dose of opioid used. For example, in NG108-15 cells nanomolar concentrations of $\delta$-opioids increased $\left[\mathrm{Ca}^{2+}\right]_{\mathrm{i}}$, while at micromolar concentrations they decreased $\left[\mathrm{Ca}^{2+}\right]_{i}$ (Jin et al., 1992). Taken at face value our data showing stimulation of $\operatorname{Ins}(1,4,5) P_{3}$ formation and inhibition of cAMP turnover suggest that the $\mu$-opioid receptor on SH-SY5Y cells is exhibiting G-protein promiscuity. In a recent report Johnson et al. (1994) described in COS cells transiently expressing the cloned opioid receptor $\mu \mathrm{OR} 1$, that promiscuity may occur to cAMP inhibition and inhibition of Ins $(1,4,5) P_{3}$ formation. However, our previous studies indicate that both events in SH-SY5Y cells are mediated by a pertussis toxin-sensitive G-protein (Smart et al., 1994a), implying Gprotein fidelity. Clearly, further studies will be required to settle this issue, using titratable levels of cloned receptors at close to endogenous concentrations.

There are two possible mechanisms for the stimulation of Ins $(1,4,5) P_{3}$ formation caused by $\mu$-opioids. First, $\beta / \gamma$ subunits from $G_{i} / G_{0}$ could activate PLC. Alternatively, $\mu$-opioids could open a $\mathrm{Ca}^{2+}$ channel, allowing $\mathrm{Ca}^{2+}$-influx-dependent activation of PLC.

Neither $\delta$-opioid nor $\alpha_{2}$ agonists stimulated $\operatorname{Ins}(1,4,5) P_{3}$ formation, while the $\mu$-opioid agonist DAMGO did (Table 1.). It is worth noting that SH-SY5Y cells do not express $\kappa$-opioid receptors (Yu et al., 1986). Furthermore, neither $\delta$-opioid nor $\alpha_{2}$ agonists enhanced the $\operatorname{Ins}(1,4,5) P_{3}$ response to a submaximal dose of DAMGO, ruling out the possibility that insufficent $\beta / \gamma$ subunits were liberated to have a stimulatory effect. Therefore, as all three of these receptors couple to $G_{i}$ (Yu et al., 1986; Lambert and Nahorski, 1990a), this indicates that $\beta / \gamma$-subunit activation of PLC, as seen in other cell types (Birnbaumer, 1992), is unlikely to occur in SH-SY5Y cells. However, $\mu$ - and $\delta$-opioid receptors couple to different subtypes of $G_{i}$ in SH-SY5Y cells (Laugwitz et al., 1993), and they may also couple differentially to $G_{0}$, as in rat cortical membranes where the two receptor subtypes couple to different types of $\mathrm{G}_{\mathrm{o}}$ (Moriaty et al., 1990; Georgoussi et al., 1993). Thus, as the type of $\beta / \gamma$ subunit varies between G-protein subtypes (Pronin and Gautam, 1992), and some reports indicate that $\beta / \gamma$-determined signal transduction is selective (Kleuss et al., 1993), there remains the possibility that $\beta / \gamma$ subunits are involved in the stimulatory effects of $\mu$-opioids in SH-SY5Y cells.

Fentanyl did not increase $\operatorname{Ins}(1,4,5) P_{3}$ formation in $\mathrm{Ca}^{2+}$-free conditions, as previously reported (Smart et al., 1994a), but subsequent $\mathrm{Ca}^{2+}$ replacement at 1 min restored the stimulatory effect. This suggests that $\mu$-opioids may open a $\mathrm{Ca}^{2+}$ channel, and that the subsequent $\mathrm{Ca}^{2+}$ influx activates PLC (Cockcroft and Thomas, 1992; Rhee and Choi, 1992). Indeed, it has recently been shown that $\mathrm{Ca}^{2+}$ activates the PLC isoform $\delta 1$ in transfected Chinese hamster ovary cells (Banno et al., 1994). While opioids generally close $\mathrm{Ca}^{2+}$ channels (Porzig, 1990), there is evidence that they can also open $\mathrm{Ca}^{2+}$ channels, as seen with $\delta$-opioids in NG108-15 cells (Jin et al., 1992). Furthermore, $\kappa$-opioids open $\mathrm{Ca}^{2+}$ channels in both astrocytes and human B cells (Heagy et al., 1992; Eriksson et al., 1993). However, this putative opening of $\mathrm{Ca}^{2+}$ channels by $\mu$-opioids was short-lived, with closing oc- 
curring in $2 \mathrm{~min}$, as indicated by the reduction in response to $\mathrm{Ca}^{2+}$ replacement (see Figure 2). Such rapid desensitization may result from receptor phosphorylation, although other mechanisms are possible (Lohse, 1993; Inglese et al., 1993).

There are several types of VSCCs (denoted L, N, T and P), each of which have different electrophysical and pharmacological properties, as well as receptor-operated $\mathrm{Ca}^{2+}$ channels (ROCC) (for review see Spedding and Paoletti, 1992). SH-SY5Y cells possess L- and N-type VSCCs (Toselli et al., 1991; Morton et al., 1992), as well as ROCCs mediating carbachol-induced $\mathrm{Ca}^{2+}$ entry, which is not sensitive to either dihydropyridines or conotoxins (Lambert et al., 1990). Nifedipine completely inhibited the fentanyl-induced $\operatorname{Ins}(1,4,5) P_{3}$ response, indicating that $\mu$-opioids may open an L-type VSCC (Spedding and Paoletti, 1992). This is in agreement with a recent study which showed $\kappa$ opioids opened L-type VSCCs in astrocytes (Eriksson et al., 1993). Furthermore, nifedipine antagonized morphine-induced analgesia in mice (Contreras et al., 1988), although this has been disputed (Omote et al., 1993; Wong et al., 1993). It is worth noting here that the $\mu$-opioid stimulation of $\operatorname{Ins}(1,4,5) P_{3}$ formation involves a pertussis toxin-sensitive G-protein (Smart et al., 1994a), and G-protein activation has been linked to $\mathrm{Ca}^{2+}$-channel opening (Dolphin and Scott, 1989).

Fentanyl caused a dose-dependent enhancement of carbacholinduced $\operatorname{Ins}(1,4,5) P_{3}$ formation. In addition, opioids enhanced Ins $(1,4,5) P_{3}$ formation induced by low doses (1-10 nM) of bradykinin in NG108-15 cells (Okajima et al., 1993). In contrast, in chromaffin cells opioids had no effect on muscarinic-induced total $\left[{ }^{3} \mathrm{H}\right]$ inositol polyphosphate accumulation (Bunn et al., 1988), although it should be noted that this method was also unable to detect the opioid-induced increase in $\operatorname{Ins}(1,4,5) P_{3}$ formation in SH-SY5Y cells (Smart et al., 1994a). This enhancement of muscarinic-induced $\operatorname{Ins}(1,4,5) P_{3}$ formation by $\mu$ opioids was additive (Table 2), unlike the synergistic enhancement of corticotrophin-releasing hormone-induced cAMP formation by opioids in the rat olfactory bulb (Olianas and Onali, 1993), suggesting that in SH-SY5Y cells the $\mu$-opioid and the $\mathbf{M}_{3}$ muscarinic receptor utilize the same pool of phosphoinositides. The enhancement of $\operatorname{Ins}(1,4,5) P_{3}$ formation was not caused by changes in either opioid or muscarinic binding, as the affinities for both carbachol and fentanyl were unchanged (Smart et al., 1994a,b), even though fentanyl has been reported to be a very weak muscarinic antagonist (Hustveit and Setekleiv, 1993; Atcheson et al., 1994).

There are many studies showing an opioid receptor-mediated reduction in neurotransmitter release (see North, 1989), and this is generally believed to be the process underlying analgesia. However, we have previously shown in SH-SY5Y cells that, while $\mu$-opioid receptor occupation reduced cAMP formation, there was no opioid-receptor-mediated inhibition of $\left[{ }^{3} \mathrm{H}\right]$ noradrenaline release (Lambert et al., 1993; Atcheson et al., 1994). Moreover, in perfused SH-SY5Y cells in the present study, fentanyl $(50 \mathrm{nM})$ failed to stimulate noradrenaline release (results not shown). This clearly indicates that the presumed increase in $\left[\mathrm{Ca}^{2+}\right]_{\mathrm{i}}$ associated with $\mu$-opioid receptor occupancy may not be sufficient to activate the secretory mechanisms. The functional role of this brief $\mathrm{Ca}^{2+}$ influx is unclear, but may be an early warning of incoming noxious stimuli or could act as a trigger to hyperpolarization.

In conclusion, we report here that activation of the $\mu$-opioid receptor briefly allows $\mathrm{Ca}^{2+}$ influx, posssibly via L-type $\mathrm{Ca}^{2+}$ channels, which stimulates PLC, leading to a transient increase in $\operatorname{Ins}(1,4,5) P_{3}$ formation, in SH-SY5Y human neuroblastoma cells. Furthermore, activation of this system can enhance muscarinic-induced PLC activity by a post-receptor mechanism. However, the possible role of this mechanism in the process of analgesia still remains unclear.

Financial support by The Wellcome Trust and Leicestershire Health Authority is gratefully acknowledged. We thank Dr. R. Atcheson for performing the studies on the effect of fentanyl on noradrenaline release.

\section{REFERENCES}

Atcheson, R., Rowbotham, D. J. and Lambert, D. G. (1994) Br. J. Anaesth. 72, 98-103 Banno, Y., Okano, Y. and Nozawa, Y. (1994) J. Biol. Chem. 269, 15846-15852

Berridge, M. J. (1993) Nature (London) 361, 315-325

Birnbaumer, L. (1992) Cell 71, 1069-1072

Brown, B. L., Albano, J. D. M., Ekins, R. P. and Sgherzi, A. M. (1971) Biochem. J. 121, 561-562

Bunn, S. J., Marley, P. D. and Livett, B. G. (1988) Biochem. Pharmacol. 37, 395-399

Camps, M., Carozzi, A., Schnabel, P., Scheer, A., Parker, P. J. and Gierschik, P. (1992) Nature (London) 360, 684-686

Carozzi, A., Camps, M., Gierschiek, P. and Parker, P. J. (1993) FEBS Lett. 315, 340-342

Challiss, R. A. J., Batty, I. H. and Nahorski, S. R. (1988) Biochem. Biophys. Res. Commun.

157, 684-691

Childers, S. R. (1991) Life Sci. 48, 1991-2003

Cockcroft, S. and Thomas, G. M. H. (1992) Biochem. J. 288, 1-14

Contreras, E., Tamayo, L. and Amigo, M. (1988) Eur. J. Pharmacol. 148, 463-466

Crain, S. M. and Shen, K. F. (1990) Trends Pharmacol. Sci. 11, 77-81

Dolphin, A. C. and Scott, R. H. (1989) in (Keeling, D. and Benham, C., eds.), pp. 127-146, Academic Press, London

Eriksson, P. S., Nilsson, M., Wagberg, M., Hansson, E. and Ronnback, L. (1993) Neuroscience 54, 401-407

Georgoussi, Z., Carr, C. and Milligan, G. (1993) Mol. Pharmacol. 44, 62-69

Heagy, W., Shipp, M. A. and Finberg, R. W. (1992) J. Immunol. 149, 4074-4081

Higashi, H., Gallagher, P. S. and Gallagher, J. P. (1982) Brain Res. 251, 186-191

Hustveit, 0. and Setekleiv, J. (1993) Acta Anaesthesiol. Scand. 37, 541-544

Inglese, J., Freedman, N. J., Koch, W. J. and Lefkowitz, R. J. (1993) J. Biol. Chem. 268, 23735-23738

Jin, W., Lee, N. M., Loh, H. H. and Thayer, S. A. (1992) Mol. Pharmacol. 42, 1083-1089 Johnson, P. S., Wang, J. B., Wang, W. F. and Uhl, G. R. (1994) NeuroReport 5, 507-509 Kleuss, C., Scherubl, H., Hescheler, J., Schultz, G. and Wittig, B. (1993) Science 259, $832-834$

Lambert, D. G. and Nahorski, S. R. (1990a) Biochem. Pharmacol. 40, 2291-2295

Lambert, D. G. and Nahorski, S. R. (1990b) Biochem. J. 265, 555-562

Lambert, D. G., Whitham, E. M., Baird, J. G. and Nahorski, S. R. (1990) Mol. Brain Res. 8 263-266

Lambert, D. G., Atcheson, R., Hirst, R. A. and Rowbotham, D. J. (1993) Biochem.

Pharmacol. 46, 1145-1150

Laugwitz, K. L., Offermanns, S., Spicher, K. and Schultz, G. (1993) Neuron 10, 233-242

Lipp, J. (1991) Clin. Pharmacol. 14, 131-147

Lohse, M. J. (1993) Biochim. Biophys. Acta 1179, 171-188

Moriaty, T. M., Padrell, E., Carty, D. J., Omri, G., Landau, E. M. and Iyengar, R. (1990)

Nature (London) 343, 79-82

Morton, A. J., Hammond, C., Mason, W. and Henderson, G. (1992) Mol. Brain Res. 13, $53-61$

North, R. A. (1989) Br. J. Pharmacol. 98, 13-28

Okajima, F., Tomura, H. and Kondo, Y. (1993) Biochem. J. 290, 241-247

Olianas, M. and Onali, P. (1993) J. Neurochem. 61, 2183-2190

Omote, K., Sonoda, H., Kawamata, M., Iwasaki, H. and Namiki, A. (1993) Anesthesiology

79, 746-752

Porzig, H. (1990) Rev. Physiol. Biochem. Pharmacol. 114, 209-262

Pronin, A. N. and Gautam, N. (1992) Proc. Natl. Acad. Sci. U.S.A. 89, 6220-6224

Rhee, S. G. and Choi, K. D. (1992) J. Biol. Chem. 267, 12393-12396

Smart, D., Smith, G. and Lambert, D. G. (1994a) J. Neurochem. 62, 1009-1014

Smart, D., Smith, G. and Lambert, D. G. (1994b) Biochem. Pharmacol. 47, 939-945

Spedding, M. and Paoletti, R. (1992) Pharmacol. Rev. 44, 363-376

Toselli, M., Rossi, M. P. and Taglietti, V. (1991) Eur. J. Neurosci. 3, 514-522

Wong, C. H., Wu, W., Yarmush, J. and Zbuzek, V. K. (1993) Life Sci. 53, PL249-253

Yu, V. C., Richards, M. L. and Sadee, W. (1986) J. Biol. Chem. 261, 1065-1070 